\title{
The Effect of Cellulose Nanocrystaline Blending to the Mechanical Properties of Composite Edible Film (PLA/CNC)
}

\author{
Rahmayetty, Endarto Y. Wardhono, Alfirano, Nufus Kanani \\ Engineering Faculty, Universitas Sultan Ageng Tirtayasa, Banten-Indonesia \\ Email: rahmayetty@untirta.ac.id
}

\begin{abstract}
Edible film is a thin and transparent plastic made from edible materials and protects material from damage due to the environment and microorganisms disaster. Polylactic acid (PLA) is one of polymer which potentially used as raw material of edible films. PLA is a very fragile nature material, so it necessary combining PLA with nanocrystaline cellulose (CNC) to improve it is properties. Combining PLA with nanocrystaline cellulose (CNC) could increase the mechanical properties of tensile strength and elongation at break of PLA. The aim of this study was to obtain the the best formulation of PLA-CNC to get the optimum tensile strength and elongation at break of PLA. The result showed that the addition of $\mathrm{CNC}$ was decrease tensile strength and increased elongation at break. The best mechanical properties of edible film is reached by using $20 \%$ CNC.
\end{abstract}

Keywords: edible film, PLA, CNC, tensile strength, elongation at break

\section{INTRODUCTION}

Packaging is a coordinated system to prepare goods to be ready to be transported, distributed, stored, sold and used. Currently, the packaging materials commonly used are plastic polymers, because they are lightweight, inexpensive, easily obtainable and shaped according to the product to be packaged. However, the use of plastic has caused serious problems. The nature of plastic that is not easily biodegradable has caused environmental damage. Another negative aspect is that plastic polymers which are not heat-resistant can cause contamination through the transmission of the monomer to packaged materials so that they do not meet food safety rules. With increasing public awareness of the importance of healthy living, encouraging the use of safer and healthier food packaging technologies. One type of packaging that is environmentally friendly is edible film and coating.

Edible film as food packaging can be formulated in the form of nano technology, which allows it to control the release of bioactive compounds contained in it (Quirós-Sauceda et al., 2014). Nanoparticles function as 
carrier material and distribute bioactive compounds throughout the food (Bouwmeester et al., 2009). One polymer that has the potential to be developed as a raw material for edible films is polylactic acid (PLA). PLA is a polymer that is biocompatible, biodegradable and derived from renewable resources (Mofokeng, JP, \& Luyt, AS., 2015). PLA can be obtained from lactic acid derived from sugar, starch and cellulose (Lasprilla et al., 2012). PLA is a non-toxic and noncarcinogenic polymer for the human body so it is very good to use for food packaging applications.

Previous research that had been carried out was the making of PLA from lactic acid by direct polycondensation method without catalyst. The optimum results obtained were at gradual polycondensation temperature $\left(150^{\circ} \mathrm{C}\right.$ for 2 hours and continued $180^{\circ} \mathrm{C}$ for 2 hours). The PLA produced had a molecular weight (Mw) of 2820. The PLA produced was brittle (Rahmayetty, 2017b). The very fragile nature of PLA with elongation at break of less than $10 \%$ will limit the polymer processing conditions (Rasal \& Hirt, 2010). PLA films for food packaging applications must have high elasticity at room temperature, transparency and low crystallinity (ElHadi, Ahmed M., 2017).

\section{Modification of PLA by} blending or composite with other polymers can improve the mechanical properties of tensile strength and elongation at break of PLA. The choice of polymer to make PLA composite material will affect the characteristics of the composite polymer produced. Cellulose is a polymer derived from plant cellulose fiber which has abundant availability. Cellulose in the form of nanoparticles or known as nanocrystaline cellulose (CNC) is commonly used to improve the mechanical properties of biopolymerbased materials (Eichhorn et al., 2010). According to Jalal Uddin et al., 2011, $\mathrm{CNC}$ has a high crystalline structure and has excellent properties such as tensile strength and elasticity modulus. $\mathrm{CNC}$ is an effective material for strengthening polymer materials. Adding $2 \%$ of $\mathrm{CNC}$ weight to poly (vinyl alcohol) (PVA) can increase modulus tests by $49 \%$ (Chen et al., 2012); the use of 5\% CNC weight into chitosan-based edible films increased tensile strength by $26 \%$ (Khan et al., 2012); and on CNC-natural rubber nanocomposite applications, both 
tensile strength and tensile modulus values increase respectively $38 \%$ and 433\% (Zhang et al., 2014). The CNC concentration added to the polymer will greatly affect the tensile strength and elongation modulus values of the composite polymer produced. Based on the description above, research on making edible coating films from PLA-CNC composites needs to be done to produce packaging material with good characteristics.

\section{MATERIAL AND METHODS}

\subsection{Materials}

Commercially available PLA pellets (PLA; Ingeo TM Biopolymer 4060D) was supplied by NatureWorks LCC, USA and cellulose nanocrystals (CNC) powders was purchased from Sigma-Aldrich, Singapore. Chloroform was obtained from Merck, Jakarta, Indonesia.

\subsection{Methods}

The CNC powder was dissolved in chloroform and then was sonicated for 5 minutes to get the dispersed phase. PLA in the form of solids was dissolved in chloroform (2 grams of PLA in $50 \mathrm{ml}$ of chloroform). The CNC that has been dispersed in chloroform was added to the PLA solution with a certain ratio. The $\mathrm{CNC}$ fraction added to the PLA solution was varied ie $2.5 \%, 5 \%, 10 \%$ and $20 \%$ (w/w). Poly ethylene glicole (PEG) was added as much as $10 \%$ as plasticizer. Melt compounding was carried out by sonicated for 10 minutes. The solution was then poured in a glass plate to form a film with a thickness of $0.5 \mathrm{~mm}$ and dried for 1 day. Chloroform drying and removal was carried out at a temperature of $60^{\circ} \mathrm{C}$. The dried film was removed from the plate and analyzed.

\subsection{Characterization of mechanical properties}

The analysis of edible film mechanical properties were tensile strength and elongation at break. Tensile strength and elongation at break weer determined using the ASTM D882-02 method. Films were cut manually into $1.5 \times 10 \mathrm{~cm}$ and then stretched by Instron $5585 \mathrm{H}$ tensometer using at a crosshead speed of 12.5 $\mathrm{mm} / \mathrm{min}$. Testing conditions include relative humidity of $50 \pm 5$ and temperature of $23 \pm 2^{\circ} \mathrm{C}$. At least 5 samples per treatment were tested and values were averaged. 


\section{RESULTS AND DISCUSSION}

\subsection{Visual of edible film}

The resulting PLA-CNC composite edible film has a white visual shape with a flexible structure, as shown in Figure 1.

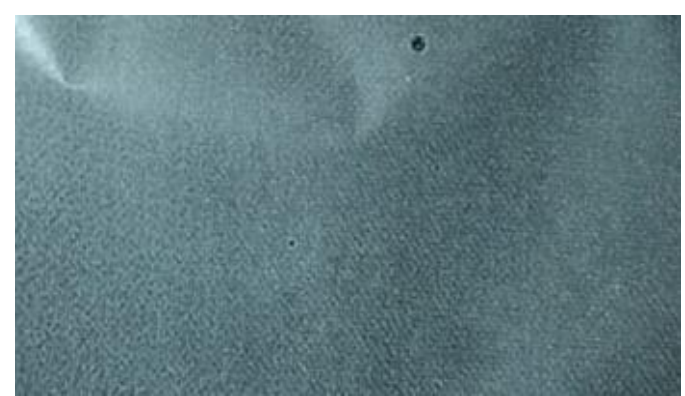

(a)

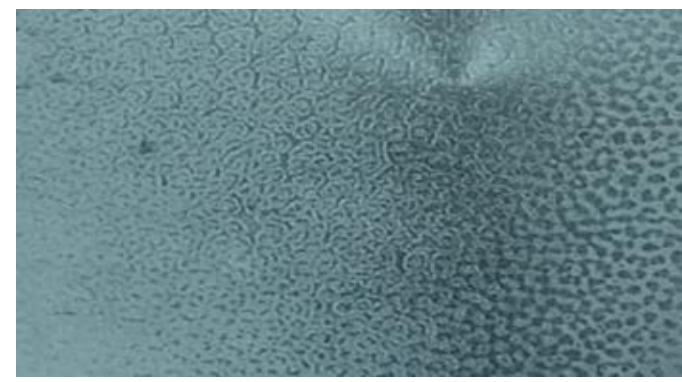

(b)

Figure 1 composite edible film of

PLA-CNC (a) $5 \% \mathrm{CNC} \quad$ (b) $20 \%$ $\mathrm{CNC}$

Increasing concentration of $\mathrm{CNCs}$ in PLA matrik causes the edible film visual form not homogeneous due to uneven PLA and CNC mixing. In this study mixing PLA and CNC using only a sonicator with a frequency of 15 $\mathrm{kHz}$ for 10 minutes and without using a homogenizer. Uneven mixing affects the shape and mechanical strength of edible films.

\subsection{Characteristics of mechanical properties of edible films}

The characteristics of the mechanical properties of the edible films produced were analyzed through tensile strength and elongation at break tests. The mechanical properties of edible films are shown in Figure 2. Figures 2 and 3 show that the addition of CNC improved the mechanical properties of edible films. The addition of $2.5 \% \quad(\mathrm{w} / \mathrm{w}) \quad \mathrm{CNC}$ from PLA produces the highest tensile strength of $15.72 \%$. The same results were also informed by Agustin et al. Increased tensile strength caused by $\mathrm{CNC}$ as a filler that fills the PLA matrix and the presence of CNC and PLA interface adhesion forces. Interface adhesion from PLA and CNC is caused by both containing hydroxyl groups that form hydrogen bonds interfaces. A strong $\mathrm{H}$ bond between the CNC and PLA faces causes effective reinforcement of the matrix. However, increasing the number of CNCs can cause damage to mechanical properties. As the number of $\mathrm{CNC}$ increases, elongation at break also increases. The highest elongation at break is $22.4 \%$ at the addition of $20 \%$ CNC. 
The increase of elongation at break from PLA-CNC blend film was caused by CNC which fills the PLA matrix and the presence of plasticizers in the form of polyethylene glycol by $10 \%(\mathrm{~W})$ of PLA and CNC total weight.

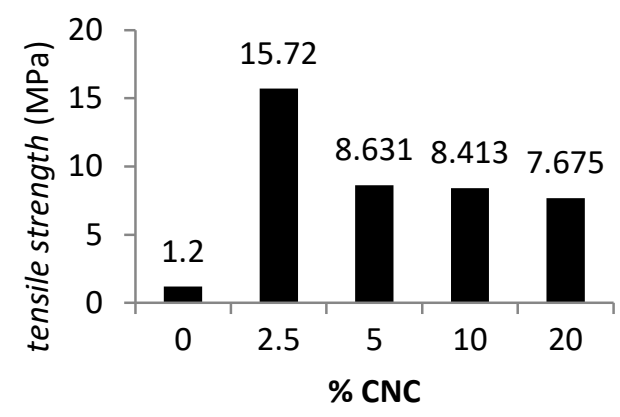

Figure 2 tensile strength edible film

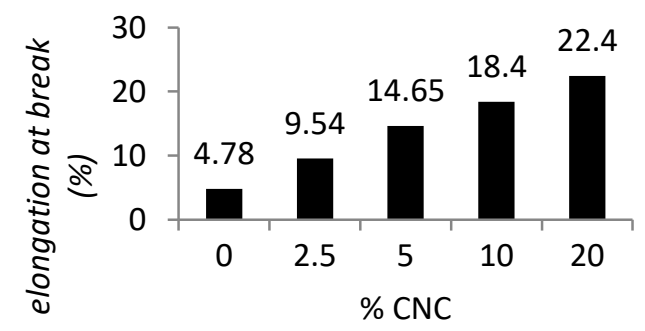

Figure 3 elongation at break edible film

Comparison of edible film results with standard edible films is shown in Table 1. Based on tensile strength and elongation at break analysis, the addition of $20 \% \mathrm{CNC}$ produces the best edible film characteristics.
Table 1 Comparison of edible film characteristics with standard of edible films

\begin{tabular}{|l|l|l|}
\hline Treatment (PLA : & $\begin{array}{l}\text { Tensil } \\
\text { e } \\
\text { streng }) \\
\text { th } \\
\text { (MPa } \\
\text { on at }\end{array}$ & $\begin{array}{l}\text { break } \\
(\%)\end{array}$ \\
\hline T1 $(100: 0)$ & 1.2 & 4.78 \\
\hline T2 $(100: 2.5)$ & 15.72 & 9.54 \\
\hline T3 (100:5) & 8.63 & 14.65 \\
\hline T4 (100:10) & 8.41 & 18.40 \\
\hline T5 (100:20) & 7.68 & 22.4 \\
\hline $\begin{array}{l}\text { Standard of edible } \\
\text { film } \\
\text { (bbp4b.litbang.kkp. } \\
\text { go.id })\end{array}$ & 2 & $25-45$ \\
\hline
\end{tabular}

\section{CONCLUSION}

Addition of CNC to PLA matrix was increase tensile strength and elongation at break from edible film. Mechanical properties of edible films that approached the standard edible film were obtained by adding $20 \% \mathrm{CNC}$ to the PLA matrix (T5 100: 20), with tensile strength and elongation at break were $7.68 \mathrm{MPa}$ and $22.4 \%$ respectively.

\section{ACKNOWLEDGMENTS}

The authors gratefully thank support from the following schemes: research 
grant from Universitas Sultan ageng

Tirtayasa through the scheme of

Penelitian Lanjutan Unggulan

Institusi: The Development of Sultan

Ageng Tirtayasa University as Center

of Excellence in Food Security for

Nation

Competitiveness

(593/UN43.9/PL/2018).

\section{REFERENCES}

Agustin, Melissa B, De Leon, Enna Richel P, Buenaobra, Jerico L, Alonzo, Shanna Marie M, Patriana, Famille M, Hirose, Fumihiko, \& Ahmmad, Bashir. Starch Based Bioplastics Reinforced with Cellulose Nanocrystals from Agricultural Residues.

Anker, M., Berntsen, J., Hermansson, A.-M., Stading, M. (2002). Improved water vapor barrier of whey protein films by addition of an acetylated monoglyceride. Innov. Food Sci. Emerg. Technol. 3, 81-92. bbp4b.litbang.kkp.go.id diakses pada 10 February 2018 pukul 10:30 WIB.

Bouwmeester, H., Dekkers, S., Noordam, M.Y., Hagens, W.I., Bulder, A.S., De Heer, C., Ten Voorde, S.E., Wijnhoven, S.W., Marvin, H.J., Sips, A.J. (2009). Review of health safety aspects of nanotechnologies in food production. Regul. Toxicol. Pharmacol. 53, 52-62.

Chen, D., Lawton, D., Thompson, M.R., Liu, Q. (2012). Biocomposites reinforced with cellulose nanocrystals derived from potato peel waste. Carbohydr. Polym. 90, 709716.
Czaja, W., Krystynowicz, A., Bielecki, S., Brown Jr, R.M. (2006). Microbial cellulose - the natural power to heal wounds. Biomaterials 27, 145-151.

Dhar, P., Tarafder, D., Kumar, A., Katiyar, V. (2015). Effect of cellulose nanocrystal polymorphs on mechanical, barrier and thermal properties of poly (lactic acid) based bionanocomposites. Rsc Adv. 5, 60426-60440.

Eichhorn, S.J., Dufresne, A., Aranguren, M., Marcovich, N.E., Capadona, J.R., Rowan, S.J., Weder, C., Thielemans, W., Roman, M., Renneckar, S. (2010). current international research into cellulose nanofibres and nanocomposites. J. Mater. Sci. $45,1$.

El-Hadi, Ahmed M. (2017). Increase the elongation at break of poly (lactic acid) composites for use in food packaging films. Scientific Reports, 7, 46767.

Falguera, V., Quintero, J.P., Jiménez, A., Muñoz, J.A., Ibarz, A. (2011). Edible films and coatings: structures, active functions and trends in their use. Trends Food Sci. Technol. 22, 292-303.

Hamad, W.Y., Chuanwei, M. (2014). Nanocomposite biomaterials of nanocrystalline cellulose (NCC) and polylactic acid (PLA).

Hossain, K.M.Z., Ahmed, I., Parsons, A.J., Scotchford, C.A., Walker, G.S., Thielemans, W., Rudd, C.D. (2012). Physico-chemical and mechanical properties of nanocomposites prepared using cellulose nanowhiskers and poly (lactic acid). J. Mater. Sci. 47, 2675-2686. 
http://www.beritasatu.com/ekonomi, diunduh pada tanggal 20 maret 2018

Hu, Y., Catchmark, J.M., Zhu, Y., Abidi, N., Zhou, X., Wang, J., Liang, N. (2014). Engineering of porous bacterial cellulose toward human fibroblasts ingrowth for tissue engineering. J. Mater. Res. 29, 2682-2693.

Jalal Uddin, A., Araki, J., Gotoh, Y. (2011). Toward "strong" green nanocomposites: polyvinyl alcohol reinforced with extremely oriented cellulose whiskers. Biomacromolecules 12, 617-624.

Jamshidian, M., Tehrany, E.A., Imran, M., Akhtar, M.J., Cleymand, F., Desobry, S. (2012). Structural, mechanical and barrier properties of active PLA-antioxidant films. J. Food Eng. 110, 380-389.

Jamshidian, M., Tehrany, E.A., Imran, M., Jacquot, M., Desobry, S. (2010). Poly-Lactic Acid: production, applications, nanocomposites, and release studies. Compr. Rev. Food Sci. Food Saf. 9, 552-571.

Khan, A., Khan, R.A., Salmieri, S., Le Tien, C., Riedl, B., Bouchard, J., Chauve, G., Tan, V., Kamal, M.R., Lacroix, M. (2012). Mechanical and barrier properties of nanocrystalline cellulose reinforced chitosan based nanocomposite films. Carbohydr. Polym. 90, 16011608.

Lasprilla, A.J., et al., (2012). Polylactic acid synthesis for application in biomedical devices-A review. Biotechnology advances. 30(1): p. 321-328.

Lin, N., Huang, J., Chang, P.R., Feng, J., Yu, J. (2011). Surface acetylation of cellulose nanocrystal and its reinforcing function in poly (lactic acid). Carbohydr. Polym. 83, 18341842.

Mofokeng, JP, \& Luyt, AS. (2015). Morphology and thermal degradation studies of meltmixed poly (lactic acid)(PLA)/poly $(\varepsilon-$ caprolactone)(PCL) biodegradable polymer blend nanocomposites with $\mathrm{TiO} 2$ as filler. Polymer Testing, 45, 93100.

Quirós-Sauceda, A.E., Ayala-Zavala, J.F., Olivas, G.I., GonzálezAguilar, G.A. (2014). Edible coatings as encapsulating matrices for bioactive compounds: a review. J. Food Sci. Technol. 51, 1674-1685.

Rahmayetty, Dhena Ria Barleany, Endang Suhendi, Bayu Prasetya, Tuti Andiyani. (2017a). Polylactic acid synthesis via Direct Polycondensation Method Using Candida rugosa lipase catalyst. World Chemical engineering journal vol 5 No.2.

Rahmayetty, Sukirno, Prasetya, Bambang, \& Gozan, Misri. (2015). Effect of Temperature and Concentration of $\mathrm{SnCl} 2$ on Depolymerization Process of Lactide Synthesis from LLactic Acid via Short Polycondensation. Vol. 10. p. 41942-41946.

Rahmayetty, Sukirno, Prasetya, Bambang, \& Gozan, Misri. (2017b). Synthesis and characterization of L-lactide and polylactic acid (PLA) from L-lactic acid for biomedical applications. Paper presented at the AIP Conference Proceedings. 
Rasal, R. M.: Janorkar, A. V. \& Hirt, D.E, (2010). Poly(lactic acid) modifications. Progress in Polymer Science, Vol.35, No.3, pp.338-356.

Shah, N., Ul-Islam, M., Khattak, W.A., Park, J.K. (2013). Overview of bacterial cellulose composites: a multipurpose advanced material. Carbohydr. Polym. 98, 1585-1598.
Zhang, C., Dan, Y., Peng, J., Turng, L.-S., Sabo, R., Clemons, C. (2014). Thermal and mechanical properties of natural rubber composites reinforced with cellulose nanocrystals from southern pine. Adv. Polym. Technol. 33. 